\title{
New Times for Women and Gender Issues in Biodiversity Conservation and Climate Justice
}

\author{
Isis Alvarez $^{1} \cdot$ Simone Lovera ${ }^{1}$
}

Published online: 10 July 2017

(C) Society for International Development 2017

\begin{abstract}
Despite early recognition of women's vital role in biodiversity conservation and increased resilience to climate change at the international policy level, only recently the Conference of the Parties to the Convention on Biodiversity has taken some concrete steps to mainstream gender in different biodiversity policies. It is expected that this increased recognition will lead to new policy approaches to enhance women's participation in tackling biodiversity loss and climate change. Such approaches can contribute to climate justice by supporting financial and other forms of support to community-driven, ecosystembased climate change mitigation and resilience initiatives that foster women's rights, needs, roles and aspirations.
\end{abstract}

Keywords Women's rights - Gender equality ·

Biodiversity conservation - Climate change mitigation .

Resilience $\cdot$ Community conservation

\section{Introduction}

Climate change impacts people differently, and it is often the most poor and vulnerable who receive the harsher impacts. Persons who face intersecting inequalities due to discrimination based on gender, gender identity, disability, race, ethnicity, economic status, age, among others, are among those populations least likely to be able to withstand

Simone Lovera

simone@globalforestcoalition.org

Isis Alvarez

isis.alvarez@globalforestcoalition.org

1 Bogota, Colombia the inevitable effects of climate change. ${ }^{1}$ Floods, forest fires, drought, and other climate change events, bear a direct brunt on rural women who depend on access to healthy ecosystems for their (and their families) livelihoods. Women and girls' roles usually entail collecting firewood, non-timber forest products, medicinal plants and other natural resources that ecosystems provide them with; they are also in charge of procuring water often having to walk long distances before they can find a safe and clean water source. If the ecosystems they interact with on a daily basis are depleted, the burden on them will increase: they would need to walk longer distances in order to find them which can bar them from education or other opportunities, for instance, or rendering them susceptible to sexual violence, or having to take care of the sick, exacerbating existing inequalities.

Women, facing the challenges imposed by climate change, have taken leadership roles in ensuring their families and communities are resilient to climate change and the risk of disasters (UNISDR 2015). Women play a key role in biodiversity conservation as they need to ensure the longterm availability of resources they use for them and their families' subsistence, as well as other associated cultural and spiritual values. Indigenous peoples and local communities worldwide have demonstrated that their conservation practices are at least as effective or even more effective than top-down biodiversity conservation approaches. Indigenous Peoples and Local Community Conserved Areas and Territories (ICCAs) and other forms of rightsbased, socially just community conservation also contribute

\footnotetext{
$\overline{1} \mathrm{http} / / / \mathrm{www}$.wedo.org/wp-content/uploads/wedo-climate-changesocial-justice.pdf.
} 
significantly to climate change mitigation and resilience. ${ }^{2} \mathrm{~A}$ growing body of literature confirms a strong correlation between the level of legal recognition of indigenous peoples' and community forest rights and their abilities to prevent deforestation, maintain forest health and connectivity, and lower carbon dioxide emissions (Nepstad et al. 2006; Nolte et al. 2013; Stevens et al. 2014). In fact, integrated community-driven approaches to ecosystem-based climate mitigation and climate resilience have proven to be one of the most effective, rights-based and socially just ways of meeting current climate change challenges. As such, they are at the heart of climate justice.

\section{Recognition of Women's Rights by the CBD}

Both the Convention on Biodiversity (CBD) and the Paris Agreement make reference to women and gender, but only recently has there been a clear recognition of the importance of women's full and effective participation in national and international policies, plans and programs by the Parties to the CBD, which met for the 13th time in December 2016 in Cancun.

During COP10, held in South Korea in 2012, the CBD adopted Decision XII/7 on mainstreaming gender considerations, ${ }^{3}$ including a Gender Plan of Action. This Decision called upon Parties (governments which have ratified the Convention) to report about the progress made on the Plan of Action. However, little has been reported by Parties in this regard. A recent study about the inclusion of gender considerations in the National Biodiversity Strategies and Action Plans (NBSAPs) from 1993 until May 2016, found that 56 percent of the NBSAPs had at least one reference to 'gender' and/or 'women', while the remaining 44 percent did not have references at all. In addition, those references were always related to 'vulnerability' or 'marginalization' ${ }^{4}$

Fortunately, the outcome of the last round of negotiations at the COP shows the deep change undergoing at the global level (and in different areas) regarding gender issues; almost 28 decisions in different areas took into account women and gender.

For instance, the decision about the engagement of different actors to mainstream biodiversity, ${ }^{5}$ recognizes the relevant role that women can play in this area taking into account their rights, needs and aspirations. Similarly, it

\footnotetext{
2 http://globalforestcoalition.org/wp-content/uploads/2016/11/Climatefinance-ICCAs-and-community-conservation-nov-2016.pdf.

${ }^{3}$ Meaning that such considerations should be taken into account throughout CBD's plans, projects, documents, etc.

${ }^{4}$ https://www.cbd.int/doc/meetings/cop/cop-13/official/cop-13-08-add 3-en.pdf.

5 UNEP/CBD/COP/13/L.31.
}

establishes a link with Sustainable Development Goal (SDG) 5 on gender equality, and the inclusion of indigenous women in the Gender Plan of Action as well as mainstreaming gender in the NBSAPs, policies and actions related to biodiversity.

In accordance to the Gender Plan of Action, the decision about progress in the implementation of the CBD Strategic Plan 2011-2020 and the Aichi Targets, ${ }^{6}$ makes a call to mainstream gender considerations into the NBSAPs and monitoring mechanisms. Another decision about cooperating with other international agreements and organizations, $^{7}$ establishes that the resolutions related to biodiversity must take into account women's participation at all levels when finalizing and implementing NBSAPs. Likewise, it establishes that there has to be an official coordination mechanism among the different national focal points and relevant authorities under the different agreements, facilitating women's participation. The decision regarding CBD's communications strategy, ${ }^{8}$ recognizes the need to include gender considerations in all resolutions, taking into account the role of women in conservation and sustainable use.

A decision on biodiversity and human health ${ }^{9}$ is very relevant because it recognizes the different roles that women and men have in managing natural resources and its relation to family's health. This decision also makes specific reference to women's reliance on ecosystems for food, water and health. In a parallel decision, collaboration with relevant organizations, including indigenous women organizations, to develop materials and tools in order to mainstream and raise awareness about the linkages between health and biodiversity was also encouraged.

The decision related to biodiversity and climate change ${ }^{10}$ recognizes gender approaches, while the decision on the Plan of Action for Ecosystem Restoration ${ }^{11}$ highlights women's participation throughout all phases of the restoration process and recognizes women as agents of change, in addition to their leadership to revitalize communities and the management of renewable resources. ${ }^{12}$ It also makes a call for gender balance in stakeholder participation, and requests capacity building on women's rights in order to implement the restoration. Decisions for CBD's implementation, ${ }^{13}$ as well as marine and coastal

\footnotetext{
${ }^{6} \mathrm{UNEP} / \mathrm{CBD} / \mathrm{COP} / 13 / \mathrm{L} .16$.

7 UNEP/CBD/COP/13/L.36.

${ }^{8} \mathrm{UNEP} / \mathrm{CBD} / \mathrm{COP} / 13 / \mathrm{L} .25$.

${ }^{9} \mathrm{UNEP} / \mathrm{CBD} / \mathrm{COP} / 13 / \mathrm{L} .26$.

${ }^{10} \mathrm{UNEP} / \mathrm{CBD} / \mathrm{COP} / 13 / \mathrm{L} .8$.

$11 \mathrm{UNEP} / \mathrm{CBD} / \mathrm{COP} / 13 / \mathrm{L} .10$.

$12 \mathrm{UNEP} / \mathrm{CBD} / \mathrm{COP} / 13 / \mathrm{L} .10$.

${ }^{13} \mathrm{UNEP} / \mathrm{CBD} / \mathrm{COP} / 13 / \mathrm{L} .5$.
} 
biodiversity, ${ }^{14}$ also request gender balance within expert groups.

The decisions on voluntary guidelines to repatriate traditional knowledge, ${ }^{15}$ and the Mo' otz kuxtal guidelines, ${ }^{16}$ where the Global Environmental Facility (GEF) and other institutions are encouraged to provide economic and technical assistance, mentions that gender should be considered while recognizing this type of women's knowledge and the need to repatriate it. The decision on funding mechanisms ${ }^{17}$ makes a call to the GEF to mainstream gender when funding biodiversity and ecosystem services.

The decision on capacity building, scientific cooperation, scientific transfer and the 'clearing house' mechanism, ${ }^{18}$ calls for workshops and trainings aimed for women and encourages the CBD Secretariat to catalyze and facilitate the engagement of women in the short-term plan for action.

Targets 18 and 16, include a reference to provide Indigenous Peoples and local community organizations with funds and technical support to organize sub-national workshops. It also establishes, as an indicator, the number of women that should benefit from the training. Other related specific activities include: mainstreaming activities with gender considerations in all biodiversity targets; to collect and disseminate tools and information about gender and biodiversity; capacity building about the Gender Plan of Action, especially for indigenous women; to organize preparatory workshops for women before the COPs, and especially for indigenous women; to provide tools and available guidelines to mainstream gender; to establish partnerships and networks to link up all national actors (women's groups) in the promotion of gender mainstreaming; to carry out assessments of the needs with women and gender experts, including indigenous women; and to collaborate with the Biodiversity Indicators Partnership to develop indicators on gender and biodiversity at the national and sub-national levels.

\section{Conclusions}

The decisions taken during CBD COP13, provide a good opportunity to move towards further progress in gender equality and women's rights and break away from technocratic approaches to biodiversity conservation and climate change mitigation; issues such as the important contribution women make to biodiversity conservation and increased resilience to climate change, require their active participation at all levels so that programs, policies and other actions at the sub-national, national, regional and international levels respond to their (women's) needs and aspirations.

Recognizing and appropriately supporting indigenous peoples and local communities' initiatives and practices in biodiversity conservation and ecosystem-based climate change mitigation and resilience, and ensuring their rights to land and resources, is a genuine investment in climate justice. Financial flows should drift away from perverse incentives and be re-directed towards addressing the underlying causes of forest loss and ecosystem degradation, with a strong consideration of women's potential contributions. So far, the patriarchal system has marginalized women in implementing biodiversity and climate commitments on the ground. What would be required to make women's role more visible, would be to break away from pre-conceived notions of women being 'weak' and 'dependent' and understand that women have historically been a key agent in leading change in different areas.

\section{References}

Nepstad, Daniel Curtis, B. Stephan Schwartzman, M. Bamberger, D.Ray Santilli, Peter Schlesinger, A. Paul Lefebvre, E.Prinz Alencar, Greg Fiske, and Alicia Rolla. 2006. Inhibition of Amazon deforestation and fire by parks and indigenous lands. Conservation Biology 20 (1): 65-73.

Nolte, Christoph, Arun Agrawal, Kirsten M. Silvius, and Britaldo S. Soares-Filho. 2013. Governance regime and location influence avoided deforestation success of protected areas in the Brazilian Amazon. Proceedings of the National Academy of Sciences of the United States of America 110 (13): 4956-4961.

Stevens, Caleb, Robert Winterbottom, Jenny Springer, and Katie Reytar. 2014. Securing rights, combating climate change: How strengthening community forest rights mitigates climate change. Washington, DC: World Resources Institute.

UNISDR. 2015. Women's leadership in risk-resilient development: Good practices and lessons learned. Bangkok: UNISDR.

\footnotetext{
${ }^{14} \mathrm{UNEP} / \mathrm{CBD} / \mathrm{COP} / 13 / \mathrm{L} .35$.

$15 \mathrm{UNEP} / \mathrm{CBD} / \mathrm{COP} / 13 / \mathrm{L} .14$.

$16 \mathrm{UNEP} / \mathrm{CBD} / \mathrm{COP} / 13 / \mathrm{L} .38$.

$17 \mathrm{UNEP} / \mathrm{CBD} / \mathrm{COP} / 13 / \mathrm{L} .37$.

18 UNEP/CBD/COP/13/L.16.
} 